Dániel Balogh

Inscriptions of the Aulikaras and Their Associates 


\section{Beyond Boundaries}

Religion, Region, Language and the State

Edited by

Michael Willis, Sam van Schaik

and Lewis Doney

Volume 4 
Dániel Balogh

Inscriptions of the

Aulikaras

and Their Associates 
Published with support of the European Research Council

Beyond Boundaries: Religion, Region, Language and the State

(Project No. 609823)

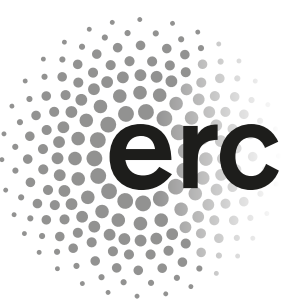

European Research Council

Established by the European Commission

ISBN 978-3-11-064472-2

e-ISBN (PDF) 978-3-11-064978-9

e-ISBN (EPUB) 978-3-11-064664-1

ISSN 2510-4446

\section{(cc) BY-NC-ND}

This work is licensed under a Creative Commons Attribution-NonCommercial-NoDerivatives 4.0 International License. For details go to http://creativecommons.org/licenses/by-nc-nd/4.0/.

\section{Library of Congress Control Number: 2019935305}

Bibliographic information published by the Deutsche Nationalbibliothek

The Deutsche Nationalbibliothek lists this publication in the Deutsche Nationalbibliografie; detailed bibliographic data are available in the Internet at http://dnb.dnb.de.

(C) 2019, Dániel Balogh published by Walter de Gruyter GmbH, Berlin/Boston The book is published with open access at www.degruyter.com.

Cover image: “Lintel,” circa 475 CE, in Sārnāth, Uttar Pradesh, India. Photograph by Michael Willis. Typesetting: Integra Software Services Pvt. Ltd.

Printing and binding: $\mathrm{CPI}$ books $\mathrm{GmbH}$, Leck

www.degruyter.com 